\title{
THE DEVELOPMENT OF A SIX SIGMA-BASED ULCUS DECUBITUS PREVENTION MODEL TO RESPOND TO ADVERSE EVENTS
}

\author{
Martini Sriwulaningdyah, Erna Dwi Wahyuni \\ Faculty of Nursing, Universitas Airlangga \\ E-mail:wulan_nal@yahoo.com
}

\begin{abstract}
Introduction: Based on the number of incidences of Ulcus Decubitus in 2015 which was $2.4 \%$ and $1.59 \%$ in 2016, the incidences of Ulcus Decubitus is an indicator of patient safety. In one of the public hospitals in Surabaya, it showed that the achievement of a Ulcus Decubitus indicator had not been reached yet (the standard is $1.5 \%$ per year). One of the efforts that can be done to prevent the occurrence of ulcus decubitus is by way of Six Sigma-based ulcus decubitus prevention. Methods: The design of this research was an explanatory research study using a cross-sectional approach. The research respondents were nurses at Inpatient Wards (4 Rooms); 57 nurses via the Purposive Sampling technique. The research data was analysed with Partial Least Square (PLS) Results: Individual factors (Path Coefficient 0,200 t: 6,580), organisational factors (Path Coefficient 0,373 t: 9,278) and management factors (Path Coefficient 0.099 t: 2.184) are all significantly correlated with the Six Sigma-based Ulcus decubitus prevention. Conclusions: Individual, Organisational and Management factors are important factors in the Six Sigma-based Ulcus Decubitus prevention model. It needs advanced research to find out how much the influence of Six Sigma-based Ulcus Decubitus prevention implementation will decrease the incidences of Ulcus Decubitus
\end{abstract}

Keywords: adverse events, prevention, six sigma, ulcus decubitus

\section{INTRODUCTION}

A hospital is an organisation that provides services to patients that should pay attention to the quality of the servicer, especially about the issue of patient safety (Iskandar, Maksum and Nafisah, 2014). Therefore patient safety is a top priority in relation to providing services to patients related to the quality issue and hospital image (Christoher, SK, David, A, Spahlinger, MD dan John, 2009). The incidences of ulcus decubitus patients is an indicator of patient safety in nursing care at the clinic (Nenny Puji Lestari, Deni Kurniadi Sunjaya and Avip Syaefullah, 2013). If the patient's safety indicator has not reached the standard $(1.5 \%$ per year), then it will affect the quality of nursing services (KARS, 2012). As a result of the frequent occurrence of ulcus decubitus, the patient is at risk of Adverse Events (Christoher, SK, David, A, Spahlinger, MD dan John, 2009). The problem is in relation to the provision of nursing care in treated patients is the unoptimised care focusing on the prevention of ulcus decubitus (Laureani, Brady and Antony, 2013). One of the efforts that can be done to prevent the occurrence of ulcus decubitus is by Six Sigma-based ulcus decubitus prevention. Diversity and service routine in the Hospital, if not managed properly, can result in Adverse Events (KTD) (Austin, 2013).
The Institute of Medicine (IOM) in 1999 published a report presenting research results in Utah and Colorado, as well as New York. In Utah and Colorado there were found to be Adverse Events at $2.9 \%$ in which $6.6 \%$ of them led to death (Mulyadi, 2010). While in New York, the number of Adverse Events was $3.7 \%$ with $13.6 \%$ mortality. The number of deaths due to Adverse Events occurred within Inpatients (33.6 million per year) in the United States ranges from 44,000-98,000 per year (Chassin, MR, Mayer, C dan Nether, 2015). Based on the 2004 World Health Organisation (WHO) publication collecting hospital research figures in various countries: America, England, Denmark and Australia, Adverse Events were found to range from 3.2 to $16.6 \%$ (Churchman, 1957). The Institute of Medicine (IOM) about the 21st-century new health system stated that in the provision of health services, patients should be safe from negligence caused by the service system (Buchbinder, BS dan Shanks, 2014). Today, the increasing complexity of health has contributed to the problem of negligence in service (Hasibuan, 2014).

Nursing care service is one part of the services provided in the Service Hospital (Kurniadi, 2013). Quality nursing care is the desire of every individual and society who receive the health care services (Cipto, 2010). Nurses as service providers need to know the standard measurement of services. The 
measurement of one of the clinical indicators of nursing quality is Ulcus Decubitus, which is coordinated by the Patient Safety Team (Graban, 2011). One of the clinical indicators of nursing quality related to patient safety namely Ulcus Decubitus - is still a problem because the achievement figure has not yet matched the standard $(\leq 1,5 \%)$ found in 20142016 (Hamming, M dan Nurnajamuddin, 2014).

The currently used Ulcus Decubitus prevention system is in the nursing process but it is still incomplete (Adisasmito, 2007). The assessment is still not focused on Ulcus Decubitus prevention. The nursing diagnoses and the nursing plans are not yet standardised, the implementation is still not optimal while monitoring and evaluations have not been done; hence there is no standard system for Ulcus Decubitus prevention (Darmawan, 2014). The nursing care system in Indonesia is still not widely published because the quality of the system is not well managed. Therefore the results of care quality have not met the expected standards yet (Komalawati; Veronica, 2010). It is necessary to conduct this research expecting that the results of this study can be useful to improve the quality of Ulcus Decubitus prevention.

\section{MATERIALS AND METHODS}

The design of this research is a crosssectional explanatory research study. The population to raise the strategic issue was sought by providing questionnaires to the nurses of an Inpatient Ward in one of the public hospitals in Surabaya, including four rooms, selected by the purposive sampling method which involved 57 managing nurses. The data was collected using a questionnaire and observation. The analysis was performed using Partial Least Square (PLS). The results of PLS and the strategic issues were then raised into FGDs with the aim of developing a module of Six Sigma-based prevention. The ethical examination was conducted on 16 March 2017 based on the ethical statement No 073/11/KOM.ETIK/2017.

\section{RESULTS}

The majority of the respondents are in adulthood, i.e. $26-30$ years old (47.4\%), with a working period as a supervisor / Team Chief for less than one year (52.6\%), while for the
Table 1. Respondent characteristics $(\mathrm{n}=57)$

\begin{tabular}{lcc}
\hline Respondent Category & $\mathbf{n}$ & $\mathbf{\%}$ \\
\hline Age & & \\
20-25 Years & 8 & 14.0 \\
26-30 Years & 27 & 47.4 \\
31-35 Years & 9 & 15.8 \\
36-40 Years & 12 & 1.8 \\
> 40Years & 21.1 \\
\hline Length of Supervisor position & & \\
< 1Years & 30 & 52.6 \\
1-5 Years & 6 & 10.5 \\
5-10 Years & 8 & 14.0 \\
10-15 Years & 2 & 3.5 \\
15 Years & 11 & 19.3 \\
\hline Last Education & & \\
Nursing Vocational School & 0 & 0 \\
Nursing Diploma & 42 & 73.7 \\
Bachelor Degree of & 15 & 26.3 \\
Nursing & & \\
\hline Employment Status & & \\
Permanent Employee & 33 & 57,9 \\
Contract Employee & 24 & 42,1 \\
\hline
\end{tabular}

last education stage undertaken by most of the respondents is a Nursing Diploma of Nursing Education (73.7\%). Most of their employment status was permanent (57.9\%) (Table 1).

\section{Data of the Individual, Organisational, and Management Factors}

The majority of the individual factors are at a good level (77.2\%). This is because the majority of the respondents have good knowledge, skills and attitude.

Major organizational factors are in good level $(70.2 \%)$ because respondents more than half responded to the environment/ provision of good infrastructure, most respondents provided good feedback, and the decision-making majority of the respondents good. Next, the majority management factor was at a good level (75.4\%) because most of the respondents answered well in relation to patient safety culture and good organisational culture.

\section{Results of PLS (Partial Least Square Output)}

\section{Analysis Results of Model Examination (Outer Model)}

The Pathway Coefficient is comprehensively presented in Table 3 . Individual factors include skill and attitude significantly influence Six Sigma-based Ulcus Decubitus prevention. Individual knowledge 
Table 2. Individual Factors, Organisational Factor and Management Factor in the Development of a Ulcus Decubitus Model based on Six Sigma on Unexpected Event (KTD) in Inpatient Room $(n=57)$

\begin{tabular}{llc}
\hline \multicolumn{1}{c}{ Factors } & n & \% \\
\hline Individual Factor & & \\
Poor & 0 & 0 \\
Fair & 13 & 22.8 \\
Good & 44 & 77.2 \\
\hline Organizational Factor & & \\
Poor & 2 & 3.5 \\
Fair & 15 & 26.3 \\
Good & 40 & 70.2 \\
\hline Management Factor & & \\
Poor & 0 & 0 \\
Fair & 14 & 24.6 \\
Good & 42 & 75.4 \\
\hline
\end{tabular}

factors have no significant effect on Six Sigma-based Ulcus Decubitus prevention. Organisation and management factors have a significant effect on Six Sigma-based Ulcus Decubitus prevention because their outer loading numbers are more than 0.5 .

\section{Analysis Results of Reliability Test (Composite Reliability)}

Composite reliability tests help to find the reliability value of an indicator of a construct. A constructor variable is said to satisfy the reliability test if it has a composite reliability value $>0.7$. All of the variables (individual factor, organisational factor, management factor and six sigma-based ulcus decubitus prevention) have a composite reliability > 0.7 (Table 4 ).

\section{Inner Model}

The inner model evaluation aims to determine the magnitude of influence or causality relationships among the variables in the study. From the table, there is an influence from the individual factors (skills, attitudes) to the prevention of ulcus decubitus based on the six sigma method. The results of Partial Least Square analysis got a statistical $t$ value of 6,580. Also, there is the influence of the organisational factors (environment, feedback, decision making) on the prevention of ulcus decubitus based on the Six Sigma method indicated by the results of the Partial Least Square analysis as it obtained a statistical $t$ value of 9,278. There is an influence from the management factor (organisational culture, patient safety culture) on the the prevention of Six Sigma-based Ulcus Decubitus. The result of the Partial Least Square analysis got a statistic $t$ value of 2.184 (Table 5).

\section{DISCUSSION}

\section{The Effects of Individual Factor on Six Sigma-based Ulcus Decubitus prevention to Inpatient Ward of Hospital}

The results of this study found that individual factors affect Six Sigma-based Ulcus Decubitus prevention. The sub-variables of the individual factors consist of the skill, knowledge and attitude of a nurse. In this case, they are related to the prevention of Ulcus Decubitus which is conducted by the nurse including assessments, planning, implementtation, and evaluation (Ardana, 2012).

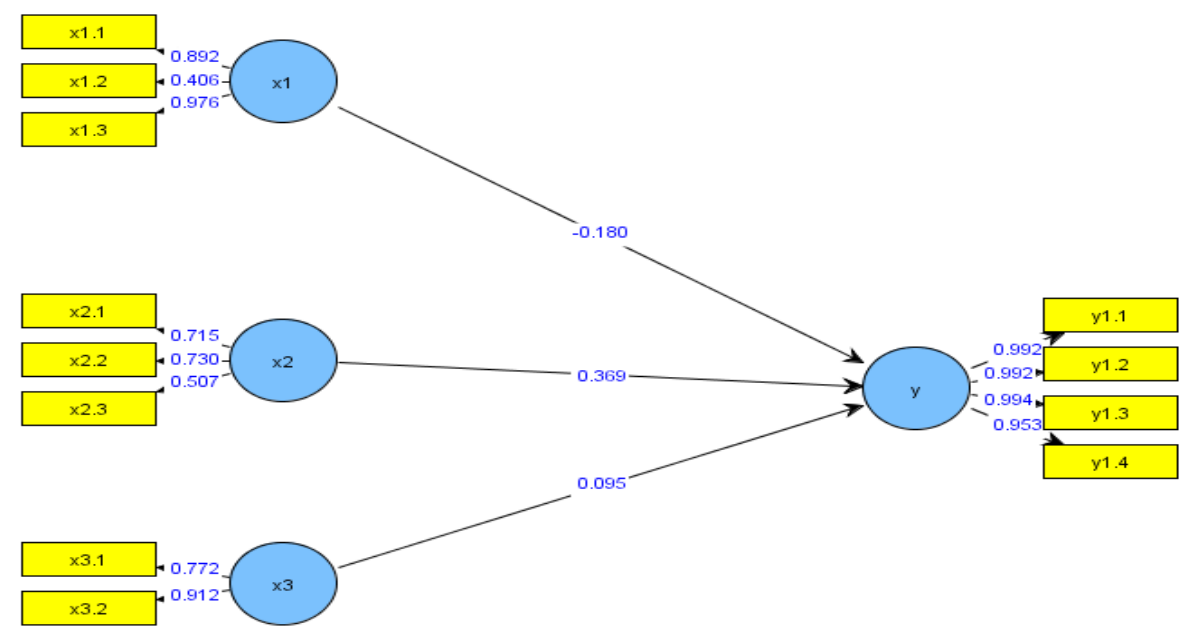

Figure 1. Analysis of the Test of Six Sigma-based Ulcus Decubitus Prevention Model 
Table 3. Recapitulation of the results of the hypothesis test of the development of a prevention model for Six Sigma based ulcers and Unexpected Events (KTD) in the Inpatient Room

\begin{tabular}{|c|c|c|c|}
\hline Variables & Indicators & Outer Loading & Remark \\
\hline \multirow[t]{3}{*}{ Individual factor } & X1.1 Skill & 0.892 & Significant \\
\hline & X1.2 Knowledge & 0.406 & Not Significant \\
\hline & X1.3 Attitude & 0,976 & Significant \\
\hline \multirow[t]{3}{*}{ Organisational factor } & X2.1 Environment & 0.715 & Significant \\
\hline & X2.2 Feedback & 0.730 & Significant \\
\hline & X2.3 Decision making & 0.507 & Significant \\
\hline \multirow[t]{2}{*}{ Management factor } & X3.1 Patient safety culture & 0.772 & Significant \\
\hline & X3.2 Organisation culture & 0.912 & Significant \\
\hline \multirow{4}{*}{$\begin{array}{l}\text { Six sigma-based Ulcus } \\
\text { Decubitus prevention } \\
\text { model }\end{array}$} & Y.1 Assessment & 0.992 & Significant \\
\hline & Y.2 Planning & 0.992 & Significant \\
\hline & Y.3 Implementation & 0.994 & Significant \\
\hline & Y.4 Evaluation & 0.953 & Significant \\
\hline
\end{tabular}

Table 4. Variable Reliability Results of individual, organisational, and management factors toward Six Sigma-based Ulcus Decubitus prevention based on Six Sigma on Unexpected Events (KTD) in the Inpatient Room

\begin{tabular}{lll}
\hline Variable & Composite Reliability & Remark \\
\hline Individual factor & 0.947 & Valid \\
\hline Organisational factor & 0.722 & Valid \\
\hline Management factor & 0.833 & Valid \\
\hline Six Sigma-based Ulcus decubitus prevention & 0.991 & Valid \\
\hline
\end{tabular}

Table 5. Hypothesis value of the variables of the individual factors, organisational factors and management factor on the prevention of Ulcus Decubitus based on Six Sigma on Unexpected Event (KTD) in the Inpatient Room

\begin{tabular}{llll}
\hline Variable & Deviation standard & T Statistic & Remark \\
\hline Individual factor & 0.030 & 6,580 & Significant \\
\hline Organisational factor & 0.040 & 9,278 & Significant \\
\hline Management factor & 0.046 & 2,184 & Significant \\
\hline
\end{tabular}

Knowledge is the result of understanding, and it occurs after sensing the object (Notoadmodjo, 2013). After a person or object has a judgment or opinion on what is known, the next process is expected to be to implement or practice what is understood (Martini, 2009). Through action and learning, one will gain trust and attitude towards something which in turn will affect behaviour (Umar, 2001).

The results of this study indicate that skills, knowledge and attitudes significantly influence Six Sigma-based Ulcus Decubitus prevention. Knowledge has two main functions, first as a background in analysing something, perceiving and interpreting it and then proceeding with a necessary action decision. The second role of knowledge in taking the necessary actions to be the background in articulating some options for possible actions, choosing one of the several possibilities and implementing the choices (Fursule, NV; Bansod, 2012). Knowledge is needed as a support in growing confidence and attitude as well as behaviour every day, so it can be said that knowledge is a fact that supports someone's attitude and actions (Notoadmodjo, 2013).

The results of the study indicate that more than $50 \%$ of nurses have skills, knowledge and a good attitude but they have undertaken less precautionary actions against Ulcus Decubitus. This is due to the low intention/motivation to work on patient care in Ulcus Decubitus prevention. The regulation/ nursing care standard of Ulcus Decubitus 
prevention has not been adjusted to the current condition, and the monitoring-evaluation of Ulcus Decubitus prevention effort has not been optimally conducted.

\section{The Effects of the Organisational Factor on Six Sigma-based Ulcus Decubitus prevention in the Inpatient Ward}

The organisational factor has subvariables such as environment, feedback and decision-making. From the results of the research, based on PLS analysis, it obtained a $\mathrm{T}$ value statistic of 9,278 . This result indicates that there is a significant influence between the variables of the organisational factor and Six Sigma-based Ulcus Decubitus prevention.

A positive work environment can reduce fatigue, attract employees and maintain work quality for the nurses (Wuryanto, 2010). The working environment consists of medical equipment and the necessary infrastructures to achieve the goal of working in a hospital (Jiwanto, A., 2015).

Feedback is one of the important things in improving the performance of a nurse (DEPKES RI, 2008). The complexity of the responsibilities to be performed is very important for the nurse whenever there is an event in relation to the patient's safety so that a similar event will not happen again (Asmuji, 2014).

Decision-making is a decision-making process in certain situations and is the main key for the health professionals in service delivery which affects various outcomes (Ammenwertha, Elske; Kutscha, Ulrike; Kutscha, Ansgar; Mahler, Cornelia; Eichstädter, Ronal; Hauxa, 2001). The results of the study on nurses states that more than $50 \%$ of the environmental factors (facilities/air mattress), for Ulcus Decubitus prevention have not matched the patients' needs. More than $50 \%$ of the nurses stated that feedback on the success rate on the Ulcus Decubitus prevention system currently has not been reinformed. This is due to the lack of existing information systems.

\section{The Effects of Management Factors on Six Sigma-based Ulcus Decubitus prevention}

Management factors have subvariables such as patient safety culture and organisational culture. From the results of this research, based on the PLS analysis, the statistical $\mathrm{T}$ value was 2,184 . The result indicates that there is a significant influence between the variables of the management factor and Six Sigma-based Ulcus Decubitus prevention.

Total safety culture mentions that there are 3 factor groups that affect patient safety culture: personal factors that tend to be from people who work in the hospital organisation, consisting of knowledge, attitude, motivation, competence and personality; organisational behavior factors that are the conditions of the work environment measured in terms of the the organisation of the health services in general, consisting of leadership, situation alertness, communication, teamwork, stress, fatigue, team leadership, and decision making; environment factors are supporters of the service processes in health organisations consisting of equipments, tools, machinery, cleanliness, and techniques (Furfari, 2010).

The results of this study states that most of the patient safety culture factors are sufficient, but it lacks the implementation of Ulcus Decubitus prevention. This is due to the lack of information about patient safety, especially about the incidence of Ulcus Decubitus which is a type of Adverse Event (KTD).

\section{CONCLUSIONS}

Individual factors (skills, knowledge, attitudes), organisational factors (environment, feedback, decision making) and management factors (patient safety culture, organisational culture) have an influence on Six Sigma-based Ulcus Decubitus prevention. It needs advanced research to find out how much the influence of Six Sigma-based Ulcus Decubitus prevention implementation will decrease the incidences of Ulcus Decubitus so that the achievement standard/indicator of Ulcus Decubitus cases can be achieved.

\section{REFERENCES}

Adisasmito, W. (2007) Sistem Manajemen Lingkungan Rumah Sakit. Jakarta: Raja Grafindo Persada.

Ammenwertha, Elske; Kutscha, Ulrike; Kutscha, Ansgar; Mahler, Cornelia; Eichstädter, Ronal; Hauxa, R. (2001) 'Nursing process documentation systems in clinical routineprerequisites and experiences', 
International Journal of Medical Informatics, 64, pp. 187-200. doi: https://doi.org/10.1016/S1386-5056 (01) 00216-7.

Ardana, K. (2012) Manajemen Sumber Daya Manusia, Ed 1. Jogyakarta: Graha Ilmu.

Asmuji (2014) Manjemen Keperawatan: Konsep dan Aplikasi,. Jakarta: ArRuzz Media.

Austin, M. (2013) 'Safety in Numbers: The Development of Leapfrog's Composite Patient Safety Score for U.S. Hospitals. Safety in Numbers.', The Johns Hopkins University School of Medicine, 9, p. 750.

Buchbinder, BS dan Shanks, H. (2014) Buku Ajar ManajemenPelayanan Kesehatan. Jakarta: EGC.

Chassin, MR, Mayer, C dan Nether, K. (2015) 'Improving Hand Hygiene at Eight Hospitals in the United States by Targeting Specific Causes of Noncompliance', The Joint Commission Journal on Quality and Patient Safety. Elsevier, 41(1), pp. 412. doi: 10.1016/S15537250(15)41002-5.

Christoher, SK, David, A, Spahlinger, MD dan John, E. . (2009) 'Creating Value in Health Care: The Case for Lean Thinking.', JCOM, 16(12).

Cipto (2010) Jaminan Mutu Layanan Kesehatan, Dasar-Dasar Pengertian dan Penerapan. Jakarta: EGC.

Darmawan, D. (2014) Metode Penelitian Kuantitatif. Bandung: Remaja Rosdakarya.

DEPKES RI (2008) Panduan Nasional Keselamatan Pasien Rumah Sakit (Patient Safety). Edited by 2. Jakarta: Bakti Husada.

Furfari, K. (2010) The Lean hospital: What does it mean? The university of Colorado Hospital.

Fursule, NV; Bansod, S. (2012) 'Understanding the Benefits and Limitations of Six Sigma Methodology.', International Journal of Scientific and Research Publications, 2(1).

Graban, M. (2011) Lean Hospital. Boca
Raton: CRC Press.

Haming, M dan Nurnajamuddin, M. (2014) Manajemen Produksi Modern, Operasi Manufaktur Faktor dan Jasa. 3rd edn. Jakarta: Bumi Aksara.

Hasibuan, S. (2014) Manajemen Sumber Daya Manusia, Jakarta: Bumi Aksara.

Iskandar, H., Maksum, H. and Nafisah, N. (2014) 'Faktor Penyebab Penurunan Pelaporan Insiden Keselamatan Pasien Rumah Sakit', Jurnal Kedokteran Brawijaya, 28(1), pp. 72-77. doi: 10.21776/ub.jkb.2014.028.01.27.

Jiwanto, A., E. (2015) Standarisasi Proses Layanan Terkait Keselamatan Pasien Melalui Pendekatan Lean Hospital di Rumah Sakit Petrokimia Gresik. Universitas Airlangga.

KARS (2012) Panduan Penyusunan Dokumen Akreditasi, Komisi Akreditasi Rumah Sakit. Jakarta.

Komalawati; Veronica (2010) Community dan Patient Safety Dalam Perspektif Hukum Kesehatan. Jakarta.

Kurniadi, A. (2013) Manajemen Keperawatan dan Prospektifnya, Teori, Konsep dan Aplikasi. Jakarta: Badan Penerbit FKUI.

Laureani, A., Brady, M. and Antony, J. (2013) 'Applications of Lean Six Sigma in an Irish hospital', Leadership in Health Services, 26(4), pp. 322-337. doi: 10.1108/LHS-01-2012-0002.

Mulyadi (2010) Sistem Perencanaan dan Pengendalian Manajemen. Jakarta: Salemba Empat.

Nenny Puji Lestari, Deni Kurniadi Sunjaya and Avip Syaefullah (2013) 'Konsep Manajemen Keselamatan Pasien Berbasis Program Di Rsud Kapuas Provinsi Kalimantan Tengah'. Available at: http://repository.unpad.ac.id/18193/ (Accessed: 14 November 2017).

Notoadmodjo (2013) Promosi Kesehatan dan Perilaku Kesehatan. Jakarta: Rineka Cipta.

Wuryanto, E. (2010) Hubungan Lingkungan Kerja dan Karakteristik Individu dengan Kepuasan Kerja Perawat di Rumah Sakit Umum Daerah Tugurejo Semarang. Universitas Indonesia. 